\title{
ANALISIS PEMILIHAN LOKASI YANG TEPAT UNTUK PEMBUATAN CABANG BARU DARI INDUSTRI JASA PIJAT NAKAMURA SEITAI DI PROVINSI MALUKU DENGAN MENGGUNAKAN METODE AHP (Analytical Hierarchy Process)
}

\author{
V. O. Lawalata \\ Program Studi Teknik Industri, Fakultas Teknik Universitas Pattimura, Ambon \\ J. M. Tupan \\ Program Studi Teknik Industri, Fakultas Teknik Universitas Pattimura, Ambon \\ Ledyweyk Kaihena \\ Program Studi Teknik Industri, Fakultas Teknik Universitas Pattimura, Ambon
}

\begin{abstract}
ABSTRAK
Banyaknya jumlah konsumen harian dari Nakamura Seitai menyebabkan fasilitas yang ada kurang memadai untuk mendukung pelaksanaan jasa pijatnya. Areal sekitar lokasi industri ini sudah padat dan sulit untuk pengembangan. Pihak manajemen memutuskan membuka cabang baru di wilayah Kota Ambon dengan mempertimbangkan 3 alternatif lokasi yaitu Urimessing, Batu Meja, Tanah Tinggi, dan Passo. Penilaian masing-masing lokasi menggunakan metode wawancara berdasarkan perspektif pemilik perusahaan. Kriteria umum seleksi lokasi adalah ukuran lokasi, biaya investasi, pasar, bahan baku, dan infrastruktur pendukung. Analisis data menggunakan metode analytical hierarchy process (AHP) menunjukkan Urimessing mendapatkan prioritas tertinggi dari pemilik perusahaan sebagai lokasi pembangunan cabang baru industri pijat tersebut.
\end{abstract}

Kata Kunci :Pemilihan Lokasi Cabang Baru, Metode Analytical Hierarchy Process

\begin{abstract}
A large number of daily consumers from Nakamura Seitai causes the existing facilities to be inadequate to support the implementation of massage services. The area around this industrial location is already congested and difficult to develop. The management decided to open a new branch in the Ambon City by considering 3 locations namely Urimessing, Batu Meja, Tanah Tinggi, and Passo. The assessment of each location uses the interview method based on the perspective of the company's owner. The general criteria for site selection are location size, investment costs, markets, raw materials, and supporting infrastructure. Data analysis using the analytical hierarchy process (AHP) method shows that Urimessing gets the highest priority from the owner as the location of the new branch construction of the massage industry.
\end{abstract}

Keywords: Selection of New Branch Location, Analytical Hierarchy Process Method

\section{PENDAHULUAN}

Sektor jasa telah menjadi salah satu penyangga ekonomi Indonesia. Dalam waktu 10 tahun (20012010) terjadi peningkatan pangsa jasa terhadap Produk Domestik Bruto (PDB) dari $44 \%$ menjadi $50 \%$ seperti halnya pangsa pekerjaan (Manning dan Aswicahyono, n.d.). jika dibandingkan dengan sektor pertanian, manufaktur, serta pertambangan dan utilitas, maka dalam periode tersebut sektor jasa berkontribusi bagi pertumbuhan PDB Nasional sekitar 7\% per tahun, pekerjaan sekitar 3\% per tahun dan produktivitas tenaga kerja mendekati $4 \%$ per tahun. Menurut Mari Elka Pangestu, sektor jasa telah mendorong peningkatan PDB Nasional dari 45\% pada tahun 2010 menjadi 55\% di tahun 2012, dimana mampu menyediakan sebanyak 21,7 lapangan kerja selama periode 2000-2010 di Indonesia (14 April 2016 pada www.dikti.go.id/industri-jasa-memiliki-potensi-besar-terhadap-peningkatan-ekonomiindonesia/). Untuk itu, industri jasa cenderung memiliki prospek bisnis yang terus berkembang dan berpotensi menjadi pilar penguatan ekonomi masyarakat di negara ini.

Industri jasa cukup banyak berkembang di wilayah-wilayah yang wilayah daratannya terbatas, sehingga relatif kurang cocok bagi industri manufaktur.Hal ini disebabkan manufaktur membutuhkan ketersediaan lahan yang relatif lebih besar untuk memudahkan tata kelola, serta penanganan limbah dan pencemaran lingkungan hidup.Oleh karena itu, daerah kepulauan yang terdiri atas pulau-pulau kecil 
seperti Provinsi Maluku, membutuhkan perencanaan yang ekstra hati-hati untuk meminimalkan dampak pencemaran dan kerusakan lingkungan.Untuk itulah, industri jasa menjadi opsi yang lebih banyak dipilih untuk dibangun dan dikembangan pada kategori wilayah ini termasuk salah satunya di Kota Ambon.

Salah satu industri jasa pijat yang terkenal di Kota Ambon adalah Nakamura Seitai.Industri ini beroperasi sejak tahun 2010 di Jl. Philip Latumahina SK 5/7, Kota Ambon dan merupakan cabang dari Nakamura Seitai Indonesia Pusat yang berada di daerah Solo, Jawa Tengah.Produk jasa yang ditawarkan berjumlah 15 jenis, yang ditangani oleh 18 orang karyawan.Konsumen dilayani antara 30-120 menit tergantung jenis produk yang digunakan.Setiap harinya, industri ini dikunjungi oleh 27-36 orang konsumen atau minimal 220 orang konsumen per karyawan.Dalam 1 bulan dapat melayani kurang lebih 4.200 orang konsumen atau mencapai 1.310 .000 orang konsumen selama 1 tahun. Konsumen cukup beragam, namun dapat dikelompokkan dalam konsumen tetap (182 orang per tahun) dan tidak tetap. Untuk melayani konsumen sebanyak itu, industri ini beroperasi dalam 2 shift yaitu shift pertama (10.00 16.30 WIT) dan shift kedua (16.30 - 22.00 WIT). Disamping manfaat pijat yang dicari konsumen, industri ini dikelola secara profesional yang mengutamakan kualitas dan kenyamanan para konsumennya, dan menggunakan standar operasional terapis. Inilah menjadikan Nakamura Seitai sebagai salah satu pilihan utama bagi masyarakat untuk mendapatkan jasa pijat di kota ini.

Banyaknya jumlah konsumen harian dari Nakamura Seitai menyebabkan fasilitas yang ada kurang memadai untuk mendukung pelaksanaan jasa pijatnya.Ruang pijat (bilik) tersedia dalam jumlah yang terbatas, sehingga sering kali konsumen harus memesan tempat beberapa waktu sebelumnya untuk mendapatkan layanan itu ataupun antri menunggu giliran di Nakamura.Daya tampung yang terbatas ini juga terasa pada fasilitas pendukung seperti areal parkir kendaraan.Areal parkir yang ada hanya mampu menampung 1 buah mobil atau 5 buah motor saja. Hal ini sering dikeluhkan oleh konsumen karena mereka sangat kuatir untuk parkir di ruas jalan umum karena akan ditilang polisi atau petugas dari dinas perhubungan kota. Mengingat areal sekitar lokasi industri sudah padat dan sulit untuk pengembangan, maka pihak manajemen berkeputusan membuka cabang baru di wilayah Kota Ambon untuk mengatasi ketidaknyamanan konsumen ini.

Dalam penilitian ini kenapa sampai menggunakan metode AHP (Analytical Hierarchy Process) adalah : Sistem Pendukung Keputusan (SPK) adalah sistem yang dapat membantu seseorang dalam mengambil keputusan yang akurat dan tepat sasaran. Ada beberapa metode yang dapat digunakan dalamm membangun suatu SPK diantaranya "analytical hierarchy process (AHP)". Metode AHP ini adalah sebuah kerangka untuk mengambil keputusan dengan efektif atas persoalan yang kompleks untuk pihak yang berkepntingan dan menarik berbagai pertimbangan guna mengembangkan bobot atau perioritas. Metode AHP ini merupakan metode yang paling banyak digunakan dalam memecahkan permasalahan yang bersifat multikriteria. Metode AHP adalah metode pengambilan keputusan untuk menentukan lokasi mana yang lebih tepat untuk pembuatan cabang baru dari industri jasa pijat Nakamura Seitai, dengan penentuan kriteria-kriteria : kriteria lokasi, biaya investasi, pasar, bahan baku, dan infrastruktur pendukung. Dengan melihat adanya kriteria-kriteria yang dipergunakan untuk mengambil keputusan, maka kan sangat cocok untuk menggunkan metode AHP dengan multikritria.

Tujuan dari penelitian ini adalah untuk menghitung bobot kriteria pemilihan lokasi, untuk menghitung bobot alternatif lokasi, untuk melakukan analisis sensitivitas alternatif lokasi dan untuk menganalisis alternatiflokasi terpilih.

\section{LANDASAN TEORI}

\section{Lokasi Fasilitas}

Lokasi fasilitas merupakan suatu proses menentukan daerah atau tempat untuk sebuah kegiatan sebuah perusahaan Kumar dan Suresh, 2008. Hasil kajian pustaka dari Pratiwi (2010: 14-17) meyajikan sejumlah teori lokasi yang relevan untuk pemilihan lokasi suatu bisnis, yaitu :

A. Von Thunnen mengembangkan teori lokasi pada awal abad 19. Thunnen melakukan pengamatan di daerah tempat tinggalnya, dari pengamatan tersebut Thunnen menemukan berbagai komoditas pertanian diusahakan menurut pola tertentu. Dengan memperhatikan jarak tempuh antara daerah produksi dan pasar, pola tersebut memasukkan variabel keawetan, berat, dan harga dari berbagai komoditas pertanian. Asumsi dari teori lokasi Von Thunnen adalah sebagai berikut

i. Terdapat suatu daerah terpencil yang terdiri dari daeerah perkotaan dengan daerah pedalamannya yang merupakan satu-satunya daerah pemasok kebutuhan pokok komoditas pertanian.

ii. Daerah perkotaan tersebut merupakan daerah penjualan kelebihan produksi daerah pedalaman dan tidak menerima penjualan hasil pertanian dari daerah lain. 
iii. Daerah pedalaman tidak menjual kelebihan produksinya ke daerah lain kecuali ke daerah perkotaan tersebut.

iv. Daerah pedalaman merupakan daerah homogen dan cocok untuk tanaman dan peternakan dataran menengah.

v. Daerah pedalaman dihuni oleh petani yang berusaha untuk memperoleh keuntungan maksimum dan mampu untuk menyesuaikan hasil tanaman dan peternakannya dengan permintaan yang terdapat didaerah perkotaan.

vi. Angkutan yang ada hanya angkutan darat berupa gerobag yang dihela kuda.

vii. Biaya angkut ditanggung oleh petani dan besarnya sebanding dengan jarak yang ditempuh. Petani menjual hasil dalam bentuk segar.

B. Melvin Greenhut berusaha menyatukan teori lokasi biaya minimum dengan teori ketergantungan lokasi.

C. Greenhut lebih menekankan segi permintan, permintaan tidak hanya ditentukan oleh lokasi tetapi juga mempengaruhi pemilihan lokasi usaha.

D. William J. Reilly menerbitkan buku pertamanya tentang model kawasan perdagangan pada tahun 1929. Hukum Reilly menyatakan gravitasi usaha berurusan dengan seberapa besar daerah perkotaan menarik pelanggan dan melayani masyarakat yang lebih kecil di pedesaan.

E. Dua dekade kemudian Paulus Converse merevisi hukum Reilly dengan menentukan batas-batas suatu kawasan perdagangan kota atau membuat sebuah "titik ketidakpedulian" antara dua kota. Titik ketidakpedulian ini adalah titik dimana pembeli akan acuh tak acuh untuk pergi ke satu kota maupun ke kota lainnya dalam upaya pemenuhan kebutuhannya.

F. Harding di dalam bukunya menjelaskan beberapa faktor yang mempengaruhi pemilihan lokasi yakni lingkungan masyarakat, sumber-sumber alam, tenaga kerja, pasar, transport, pembangkit tenaga, dan tanah untuk ekspansi. Lingkungan masyarakat adalah kesediaan dari masyarakat disuatu daerah untuk menerima segala konsekuensi baik konsekuensi positif maupun konsekuensi negatif daripada didirikannya suatu tempat usaha didaerah tersebut merupakan suatu syarat untuk dapat atau tidaknya didirikannya usaha tersebut didaerah itu. Besarnya populasi, kepadatan penduduk, dan karakteristik masyarakat menjadi faktor dalam mempertimbangkan suatu area perdagangan. Basis ekonomi yang ada seperti industri daerah setempat, potensi pertumbuhan, fluktuasi karena faktor musiman, dan fasilitas keuangan di daerah sekitar juga harus diperhatikan oleh pemilik dalam memilih lokasi usahanya.

G. Menurut Alcacer dengan lokasi yang berdekatan dengan pesaing usaha, perusahaan dapat melakukan strategi kompetisi total baik dalam kepemimpinan harga atau jasa lain yang diberikan. Seorang pengusaha harus mengenali jumlah dan ukuran usaha lain serta situasi persaingan yang ada di daerah tersebut.

\section{Analytical Hierarchy Process (AHP)}

AHP merupakan alat pendukung keputusan untuk memecahkan masalah komplek (Triantaphyllou dan Mann, 1995) secara sistematis, menggunakan pendekatan matematis yang cukup sederhana untuk menguraikan faktor atau kriteria ganda yang kompleks menjadi suatu hirarki. Hirarki menyatakan sebuah permasalahan yang kompleks dalam suatu struktur multi-level dimana level pertama adalah tujuan (goal), yang diikuti level kriteria, sub kriteria, dan seterusnya ke bawah hingga level terakhir berupa alternatif (Saaty, 1988). Oleh karena itu terdapat beberapa komponen penting dalam AHP, yaitu tujuan, kriteria/sub kriteria, alternatif keputusan, dan relasi (antar kriteria dan sub kriteria; antar kriteria dan tujuan; serta kriteria/sub kriteria dengan alternatif keputusan). Dengan demikian, pada struktur hirarki permasalahan keputusannya, alternatif keputusan akan terhubung dengan tujuan melalui relasi kriteria dan sub kriteria.

Pendekatan AHP ini didasarkan pada 3 prinsip perilaku manusia, yaitu:

1. Dekomposisi sebuah permasalahan kompleks untuk memahaminya.

2. Perbandingan bagian-bagiannya untuk menentukan tingkat atau intensitas interaksi dan pengaruh secara keseluruhan.

3. Sintesis untuk menggabungkan pemahaman dan pengetahuan secara keseluruhan.

Mengacu pada praktek penggunaan AHP, maka terdapat beberapa tahapan implementasi pendekatan ini, yaitu:

1. Identifikasi tujuan, atribut (kriteria/sub kriteria), dan alternatif keputusan.

2. Konstruksikan hirarki keputusan.

3. Lakukan perbandingan berpasangan (pairwise comparison) dari atribut (kriteria/sub kriteria) dan alternatif.

4. Tranformasikan nilai perbandingan dalam bobot. 
5. Periksa inkonsistensi hasil perbandingan berpasangan.

6. Kalkulasi skor setiap alternatif menggunakan bobot.

7. Rekomendasikan keputusan sementara.

8. Lakukan analisis sensitifitas.

Dalam AHP, hirarki disajikan mirip dengan pohon nilai pada SMART. Perbedaan yang signifikan adalah bahwa pada AHP, alternatif keputusan digambarkan pada bagian bawah dari atribut level terbawah.

\section{Perbandingan Berpasangan Dan Bobot}

Perbandingan ini menyatakan seberapa penting satu atribut atau alternatif terhadap satu atribut atau alternatif yang lain. Proses ini berulang untuk semua atribut se-level dalam komponen induk (tujuan atau atribut) yang sama. Tingkat kepentingan diukur dalam skala antara 1 sampai 9.Jika $\mathrm{C}$ menyatakan kriteria, S adalah sub kriteria Hasil perbandingan berpasangan disajikan dalam bentuk matriks $(\boldsymbol{A})$, yaitu:

$$
\boldsymbol{A}=\begin{gathered}
S_{1} \\
S_{2} \\
\cdots \\
S_{n}
\end{gathered}\left[\begin{array}{cccc}
a_{11} & S_{2} & \cdots & S_{n} \\
a_{21} & a_{22} & \cdots & a_{2 n} \\
\cdots & \cdots & \cdots & \cdots \\
a_{n 1} & a_{n 2} & \cdots & a_{n n}
\end{array}\right] \cdots .
$$

Oleh karena bobot dinyatakan oleh vektor $\mathrm{W}=\left(\mathrm{w}_{1}, \mathrm{w}_{2}, \ldots, \mathrm{w}_{\mathrm{n}}\right)$ dan $\mathrm{w}_{\mathrm{n}}$ adalah bobot relatif, maka :

$$
\begin{aligned}
& a_{i j}=\frac{w_{i}}{w_{j}} \ldots . . \\
& \boldsymbol{W}=\left[\begin{array}{l}
w_{1} \\
w_{2} \\
\cdots \\
w_{n}
\end{array}\right]
\end{aligned}
$$

untuk $\mathrm{i}, \mathrm{j}=1, \ldots, \mathrm{n}$, maka:

$$
\boldsymbol{A} \boldsymbol{W}=n \boldsymbol{W}
$$

$\boldsymbol{W}$ menyatakan faktor eigen dan $n$ adalah nilai eigen. $\mathrm{n}$ dapat diganti dengan vektor $\lambda$, sehingga:

$$
A W=\lambda W
$$

dimana $\lambda=\left(\lambda_{1}, \lambda_{2}, \ldots, \lambda_{n}\right)$. Matriks $\boldsymbol{A}$ merupakan matrik konsisten sehingga salah satu nilai eigen adalah $n$ dan lainnya bernilai 1 . Jika matriks tidak konsisten, nilai eigen terbesar $\left(\lambda_{\max }\right)$ mendekati $\mathrm{n}$ dan yang lainnya mendekati 0 , sehingga:

$$
A W=\lambda_{\max } W \quad \ldots
$$

\begin{tabular}{|c|c|c|c|c|c|c|}
\hline \multicolumn{2}{c|}{ Perbandingan Berpasangan } \\
\hline Kriteria & $\mathrm{S}_{1}$ & $\mathrm{~S}_{2}$ & $\ldots$ & $\mathrm{S}_{\mathrm{N}}$ & $\begin{array}{c}\text { Rataan } \\
\text { Geometrik }\end{array}$ & $\begin{array}{c}\text { Nilai Eigen } \\
\text { (Bobot) }\end{array}$ \\
\hline $\mathrm{S}_{1}$ & $\mathrm{a}_{1} / \mathrm{a}_{1}$ & $\mathrm{a}_{1} / \mathrm{b}_{2}$ & $\ldots$ & $\mathrm{a}_{1} / \mathrm{b}_{\mathrm{n}}$ & $\mathrm{G}_{1}$ & $\lambda_{1}$ \\
\hline $\mathrm{S}_{2}$ & $\mathrm{a}_{2} / \mathrm{b}_{1}$ & $\mathrm{a}_{2} / \mathrm{b}_{2}$ & $\ldots$ & $\mathrm{a}_{2} / \mathrm{a}_{\mathrm{n}}$ & $\mathrm{G}_{2}$ & $\lambda_{2}$ \\
\hline$\ldots$ & $\ldots$ & $\ldots$ & $\ldots$ & $\ldots$ & $\ldots$ & $\ldots$ \\
\hline $\mathrm{S}_{\mathrm{n}}$ & $\mathrm{a}_{\mathrm{n}} / \mathrm{a}_{1}$ & $\mathrm{a}_{\mathrm{n}} / \mathrm{a}_{2}$ & $\ldots$ & $\mathrm{a}_{\mathrm{n}} / \mathrm{a}_{\mathrm{n}}$ & $\mathrm{G}_{\mathrm{N}}$ & $\lambda_{\mathrm{N}}$ \\
\hline
\end{tabular}

Nilai bobot kepentingan $\left(a_{i} / a_{j}\right.$, dimana $\left.i, j=1, \ldots, n\right)$ menyatakan seberapa penting kriteria 1 dari kriteria lain terhadap tujuan. Skala bobot adalah antara 1 sampai 9 (tabel 7.1). Untuk mendapatkan nilai bobot, hitung rataan geometrik $(G)$ dari baris sebagai berikut :

$$
G_{i}=\sqrt[n]{\frac{a_{1}}{a_{1}} x \cdots x \frac{a_{n}}{a_{n}}} \quad \cdots .
$$

Nilai eigen merupakan hasil normalisasi indeks yang menyatakan bobot setiap kriteria.

$$
\lambda_{i}=\frac{G_{i}}{\sum G}
$$




\section{Inkosistensi}

Dalam prakteknya, kondisi ideal dimana matriks A adalahkonsisten sulit diperoleh, sehingga nilai $\lambda_{\max }$ cenderung lebih besar dari $n$. Ukuran inkonsistensi akan memperbaiki tingkat konsistensi penilaian. Inkonsistensi menunjukan rata-rata tingkat perbedaan nilai $\lambda_{\max }$ dalam perbandingan berpasangan. Penentuannya berdasarkan nilai ini berdasarkan nilai consistency index (C.I.) dan consistency ratio (C.R.).

$$
\begin{aligned}
& C . I .=\frac{\lambda_{\max }-n}{n-1} \\
& C . R .=\frac{C . I}{R . I} \ldots . .
\end{aligned}
$$

Random consistency index (R.I.) merupakan hasil generalisasi indeks konsistensi secara random menggunakan skala 1/9, 1/8, .., 8, 9 (Saaty, 1996). Jika C.R.<0, maka konsistensi lebih tinggi, dan sebaliknya inkonsistensi yang lebih tinggi C.R. >0.

Random consistency index

\begin{tabular}{ccccccccccc}
\hline$n$ & 1 & 2 & 3 & 4 & 5 & 6 & 7 & 8 & 9 & 10 \\
\hline R.I R.I. & 0 & 0 & 0,52 & 0,89 & 1,11 & 1,25 & 1,35 & 1,40 & 1,45 & 1,49 \\
\hline
\end{tabular}

(sumber: Saaty, 1996)

Batas inkonsistensi penilaian yang perkenankan adalah kurang dari 0,10 (Saaty, 1996)

\section{Skor Alternatif}

Hasil perbandingan berpasangan menyajikan nilai bobot lokal $(w)$ bagi setiap alternatif, sub krteria, atau kriteria. Kombinasi dari bobot lokal ini membentuk skor akhir atau prioritas alternatif. Jika A menyatakan altenatif, $\operatorname{Pr}\left(\mathrm{A}_{\mathrm{i}}\right)$ adalah prioritas alternatif ke-i dan $w_{\mathrm{i}}$ merupakan bobot lokalnya, maka

$$
\operatorname{Pr}\left(A_{i}\right)=\sum_{i=1}^{k} w_{i} \operatorname{Pr}_{i}\left(A_{i}\right) \quad \text {.... }
$$

\section{Analisis Sensitif}

Analisis ini menentukan sejauh mana keputusan yang sama akan bertahan dengan perubahan tingkat prioritas. Proses ini dilakukan dengan merubah-rubah nilai bobot kriteria atau sub kriteria. Hasilnya akan menunjukan interval skor (minimum dan maksimum) dari setiap kriteria atau sub kriteria yang akan merubah keputusan.

\section{METODE PENELITIAN}

\section{Variabel dan Definisi Operasional}

Variabel keputusan dapat dinotasikan dengan lambang X. Yang termasuk dalam indikator variabel keputusan dalam penilitian adalah sebagai berikut :

a. Kriteria Ukuran Lokasi (Indeks 0-1) $\left(\mathrm{X}_{1}\right)$

b. Kriteria Biaya Investasi (Indeks 0-1) $\left(\mathrm{X}_{2}\right)$

c. Kriteria Pasar (Indeks 0-1) $\left(\mathrm{X}_{3}\right)$

d. Kriteria Bahan Baku (Indeks 0-1) $\left(\mathrm{X}_{4}\right)$

e. Kriteria Infrastruktur Pendukung (Indeks 0-1) $\left(\mathrm{X}_{5}\right)$

Variabel keputusan merupakan suatu indikator untuk mencapai variabel tujuan. Yang mana variabel tujuan adalah Alternatif Pemilihan Lokasi Gedung Baru Pijat Nakamura.

\section{Metode Analisa Data}

Pengolahan data yang terkumpul dalam penelitian ini mengikuti tahapan pada Metode analytical hierarchy process (AHP). Untuk itu tahapan analisis dalam penelitian ini adalah:

a. Lakukan perbandingan berpasangan (pairwise comparison) dari atribut (kriteria/sub kriteria) dan alternatif.

b. Tranformasikan nilai perbandingan dalam bobot.

c. Periksa inkonsistensi hasil perbandingan berpasangan.

d. Kalkulasi skor setiap alternatif menggunakan bobot.

e. Rekomendasikan keputusan sementara.

f. Lakukan analisis sensitifitas. 


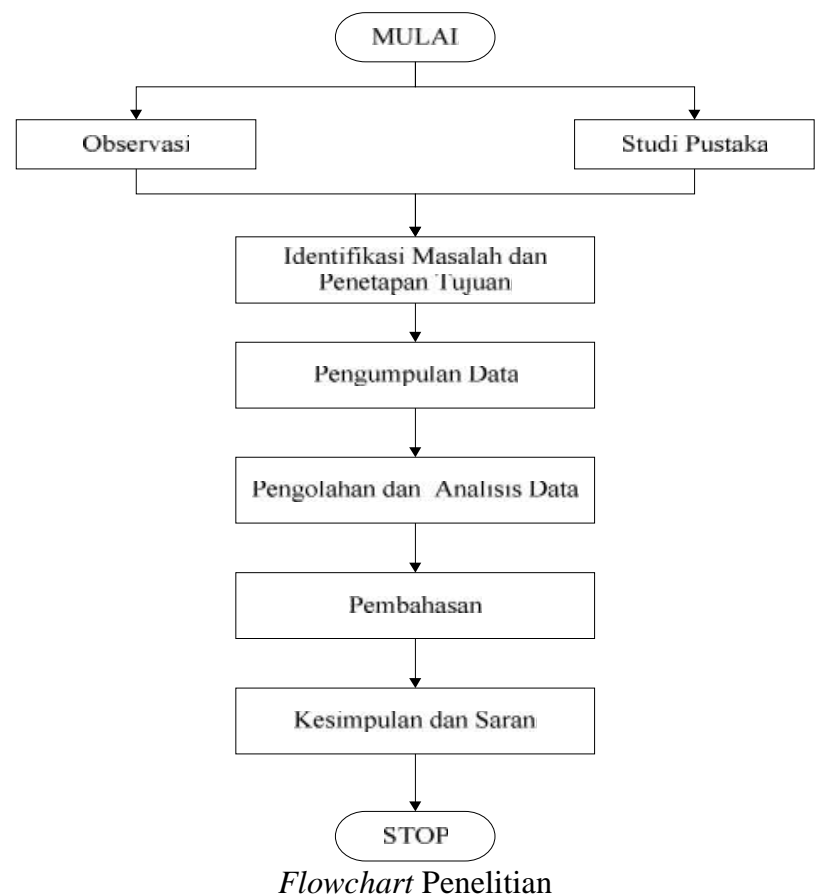

\section{HASIL DAN PEMBAHASAN}

\section{Operasional Nakamura}

Nakamura menyediakan sumber daya yang releva untuk menunjang bisnisnya. Karyawan perusahaan ini merupakan gabungan dari pekerja laki-laki (7 orang) dan perempuan (11 orang). Tempat ini beroperasi menggunakan sistem shift kerja, dimana shift kerja pertama dimulai pada jam 10.00 WIT sampai 16.30 WIT dan shift kerja kedua berlangsung pada 16.30 WIT sampai 22.00 WIT. Karyawan yang terlibat di setiap shift kerja berjumlah 9 orang.

Bisnis ini memiliki jumlah pelanggan yang banyak dalam beberapa kategori.Setiap hari sekitar 2736 pelanggan yang menggunakan jasa pijat dimana setiap karyawan dapat melayani sampai 4 pelanggan. Walaupun bergantung pada tingkat keramaian, namun pelanggan yang menggunakan jasa pijat dapat mencapai 220 orang/minggu atau sekitar 4.200 orang/bulan. Diantara pelanggan tersebut, terdapat 182 pelanggan tetap/tahun yang terdiri atas 46 pelanggan tetap VIP dan 136 pelanggan tetap regular.

Identifikasi tujuan, atribut (kriteria/sub kriteria), dan alternatif keputusan

1) Tujuan: merekomendasikan alternatif lokasi pembangunan gedung cabang baru yang tepat dari Industri Jasa Pijat Nakamura Seitai di Kota Ambon;

2) Atribut dan Sub Atribut, yang ditentukan berdasarkan keputusan Pemilik Industri Jasa Pijat Nakamura Seitai sebagai satu-satunya pengambil keputusan di industri ini, meliputi:

i. Atribut 1: Lokasi, dengan 2 Sub Atribut yakni Luas Lokasi dan Luas Tempat Parkir;

ii. Atribut 2: Biaya Investasi, dengan 2 Sub Atribut yakni Harga Tanah dan Sewa Lahan/Gedung;

iii. Atribut 3: Pasar, dengan 4 Sub Atribut yakni Kedekatan dengan Konsumen, Tingkat Pendapatan Konsumen, Tingkat Pengeluaran Konsumen, dan Tingkat Persaingan Antar Usaha Sejenis;

iv. Atribut 4: Bahan Baku, dengan 3 Sub Atribut yakni Kedekatan dengan Lokasi Sumber Bahan Baku, Harga Bahan Baku, dan Tingkat Ketersediaan Bahan Baku;

v. Atribut 5: Infrastruktur Pendukung, dengan 4 Sub Atribut yakni Tingkat Ketersediaan Air Bersih, Ketersediaan Jaringan Listrik, Kedekatan dengan Jalan Utama, dan Tingkat Kedekatan Fasilitas Keamanan.

3) Alternatif Keputusan, merupakan alternatif lokasi pembanguan cabang baru dari industri pijat tersebut yakni Passo, Batu Meja, Tanah Tinggi, dan Urimesing 


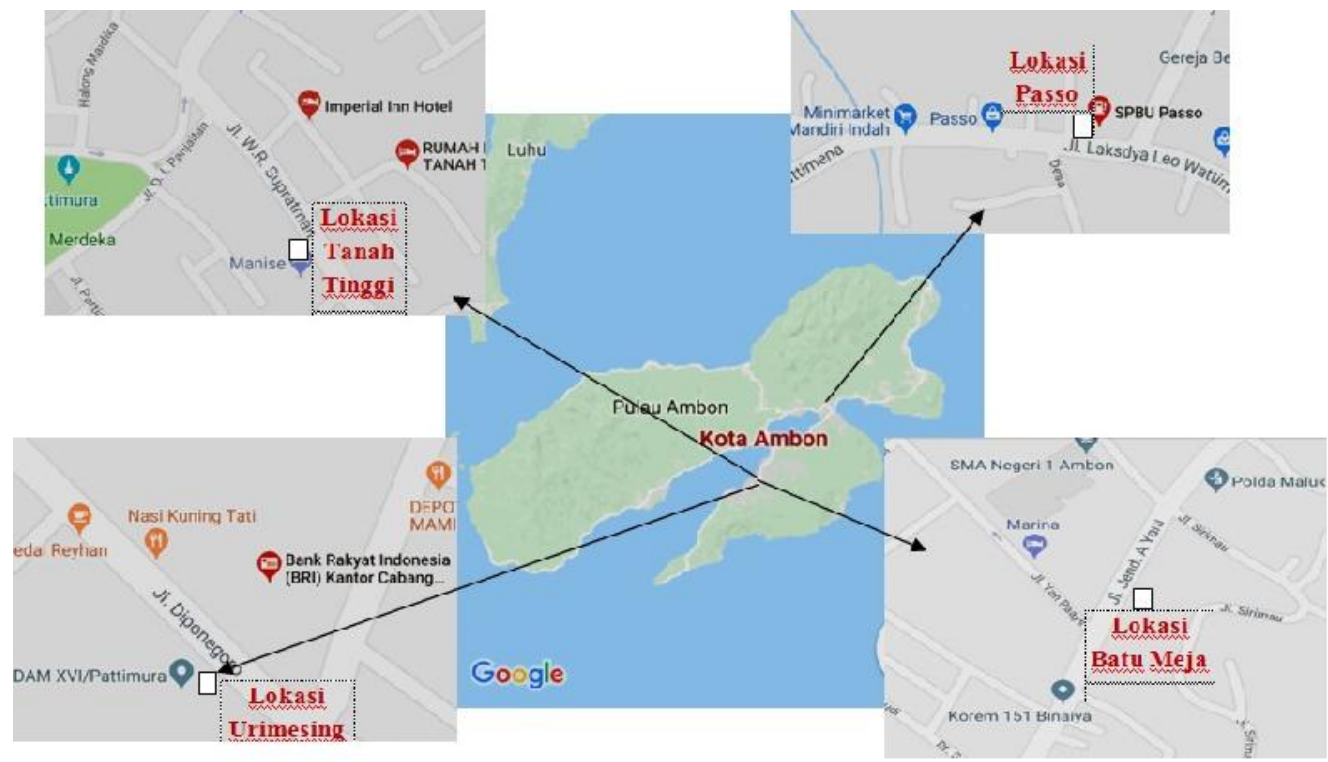

Posisi Lokasi Alternatif Lokasi Cabang Baru Industri Jasa Pijat Nakamura Seitai

b. Konstruksi Hirarki Keputusan

Hirarki keputusan dikonstruksikan dalam bentuk pohon keputusan yang menyajikan relasi antara Kriteria, Sub Kriteria dan Alternatif Lokasi

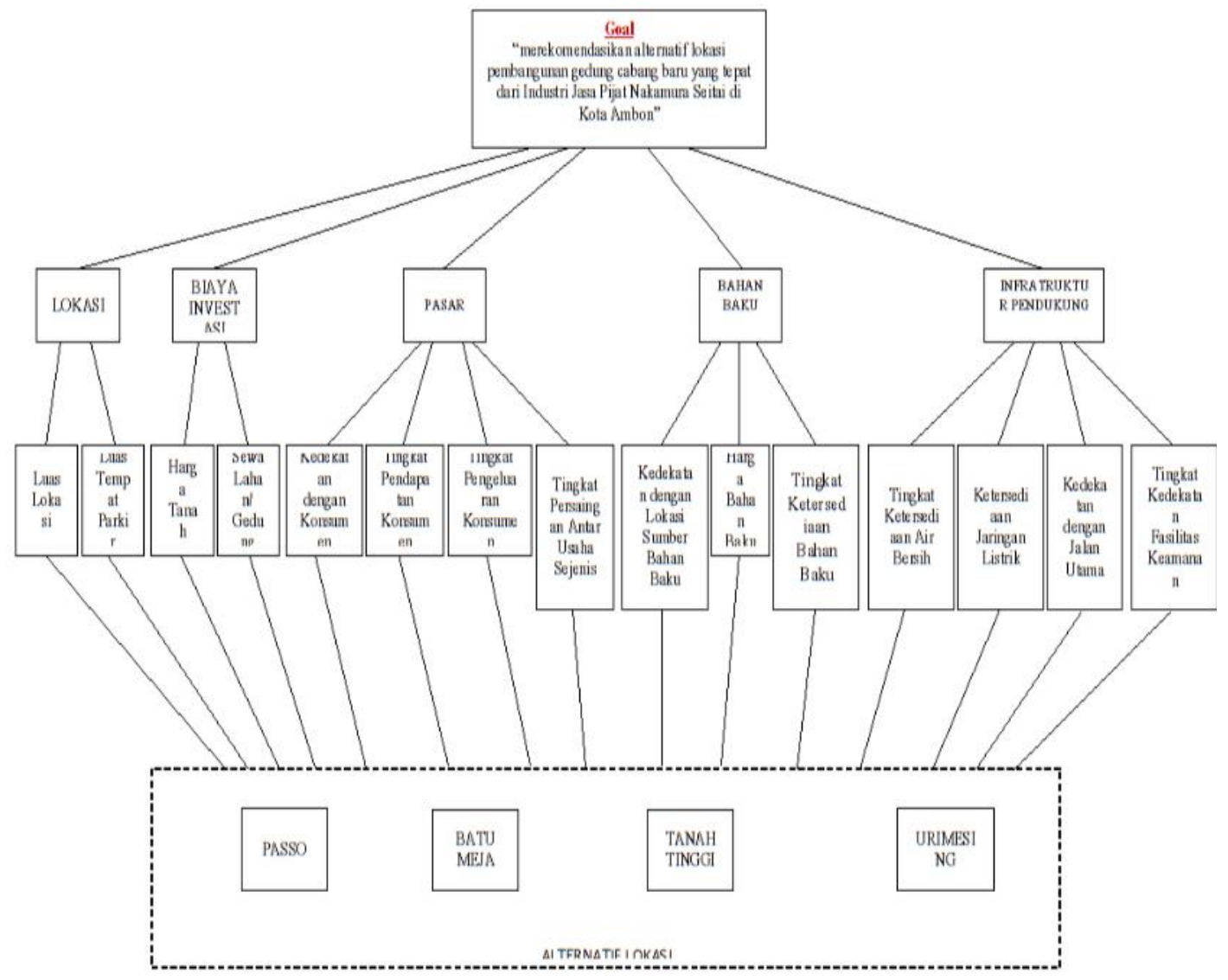

Hirarki Keputusan 
c. Perbandingan Berpasangan

1. Level Kriteria

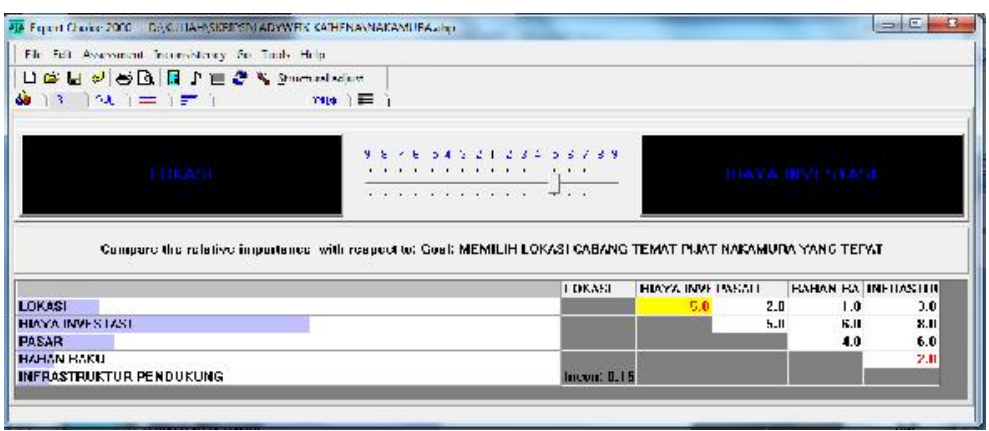

Pengolahan data level kriteria dengan software expert choice

i. Matriks Perbandingan Berpasangan

$$
\begin{aligned}
A & \left.=\begin{array}{ccccc}
1 & 1 / 5 & 2 & 1 & 3 \\
5 & 1 & 5 & 6 & 8 \\
1 / 2 & 1 / 3 & 1 & 4 & 6 \\
1 & 1 / 6 & 1 / 4 & 1 & 1 / 2 \\
1 / 3 & 1 / 8 & 1 / 6 & 2 & 1
\end{array}\right] \\
& =\left[\begin{array}{ccccc}
1 & 0.2 & 2 & 1 & 3 \\
5 & 1 & 5 & 0 & 8 \\
0.5 & 0.2 & 1 & 4 & 6 \\
1 & 0.16666 / & 0.25 & 1 & 0.5 \\
0.333333 & 0.125 & 0.16666 / & 2 & 1
\end{array}\right]
\end{aligned}
$$

ii. Bobot Relatif yang Dinormalisasi $(W)$

Perhitungan bobot relatif yang dinormalisasikan menggunakan Rataan Geometrik untuk setiap baris Kriteria pada matriks perbandingan berpasangan, yaitu:

a) Normalisasi perbandingan berpasangan

Perhitungan normalisasi dilakukan secara kolom pada hasil perbandingan berpasangan. Normalisasi untuk setiap sel pada matriks perbandingan berpasangan mengikuti rumus sebagai berikut:

$\frac{a_{i j}}{\sum_{i=1}^{5} a_{i j}}=\frac{a_{i j}}{a_{. j}}$

Perbandingan Berpasangan Dengan Jumlah Kolom

\begin{tabular}{|l|c|c|c|c|c|}
\hline \multicolumn{1}{|c|}{ Kriteria } & Lokasi & $\begin{array}{c}\text { Biaya } \\
\text { Investasi }\end{array}$ & Pasar & $\begin{array}{c}\text { Bahan } \\
\text { Baku }\end{array}$ & $\begin{array}{c}\text { Infrastruktur } \\
\text { Pendukung }\end{array}$ \\
\hline Lokasi & 1 & 0.2 & 2 & 1 & 3 \\
\hline Biaya Investasi & 5 & 1 & 5 & 6 & 8 \\
\hline Pasar & 0.5 & 0.2 & 1 & 4 & 6 \\
\hline Bahan Baku & 1 & 0.1666667 & 0.25 & 1 & 0.5 \\
\hline Infrastruktur Pendukung & 0.3333333 & 0.125 & 0.1666667 & 2 & 1 \\
\hline \multicolumn{1}{|c|}{$a_{. \mathrm{i}}$} & 7.833333 & 1.691667 & 8.416667 & 14 & 18.5 \\
\hline
\end{tabular}

Hasil normalisasi untuk sel $a_{11}$ adalah

$\frac{a_{11}}{a_{.1}}=\frac{1}{7.833333}=0.127660$

Perbandingan Berpasangan yang Dinormalisasikan

\begin{tabular}{|l|c|c|c|c|c|}
\hline \multicolumn{1}{|c|}{ Kriteria } & Lokasi & $\begin{array}{c}\text { Biaya } \\
\text { Investasi }\end{array}$ & Pasar & $\begin{array}{c}\text { Bahan } \\
\text { Baku }\end{array}$ & $\begin{array}{c}\text { Infrastruktur } \\
\text { Pendukung }\end{array}$ \\
\hline Lokasi & 0.127660 & 0.118227 & 0.237624 & 0.071429 & 0.162162 \\
\hline Biaya Investasi & 0.638298 & 0.591133 & 0.594059 & 0.428571 & 0.432432 \\
\hline Pasar & 0.063830 & 0.118227 & 0.118812 & 0.285714 & 0.324324 \\
\hline Bahan Baku & 0.127660 & 0.098522 & 0.029703 & 0.071429 & 0.027027 \\
\hline Infrastruktur Pendukung & 0.042553 & 0.073892 & 0.019802 & 0.142857 & 0.054054 \\
\hline
\end{tabular}


b) Rataan Geometrik Kriteria (Bobot Relatif $\left(w_{\mathrm{j}}\right)$ )

- Kriteria Lokasi

$$
\begin{gathered}
w_{1}=G_{1}=\prod_{j=1}^{m} \mid a_{i} \\
=\sqrt[5]{0.127660 \times 0.118227 \times 0.237624 \times 0.071429 \times 0.162162} \\
=0.1329523
\end{gathered}
$$

- Kriteria Biaya Investasi

$$
\begin{aligned}
& w_{2}=G_{2} \\
& =0.5292928
\end{aligned}
$$

- Kriteria Pasar

$$
\begin{aligned}
& w_{3}=G_{3} \\
& =0.1527221
\end{aligned}
$$

- Kriteria Bahan Baku

$$
\begin{aligned}
& w_{4}=G_{4} \\
& =0.0591033
\end{aligned}
$$

- Kriteria Infrastruktur Pendukung

$$
\begin{aligned}
& w_{5}-G_{5} \\
& =0.0544996
\end{aligned}
$$

Berdasarkan hasil perhitungan diatas, diperoleh matriks bobot relatif yang dinormalisasikan $(W)$ sebagai berikut:

$$
W=\left[\begin{array}{l}
0.1329523 \\
0.5292928 \\
0.1577721 \\
0.0591033 \\
0.0511466
\end{array}\right]
$$

iii. Eigen Value Terbesar $\left(\lambda_{\max }\right)$

$$
\begin{aligned}
& A W=\lambda_{\max } W \\
& \begin{array}{ccc}
\mathbf{1} & 0.2 & 2 \\
5 & 1 & 5 \\
0.5 & 0.2 & 1 \\
\mathbf{1} & 0.16666 \gamma & 0.25 \\
0.3333333 & 0.125 & 0.1666 \\
0.13295 \\
0.52929 \\
0.152 / 22 \\
0.059103 \\
0.054495
\end{array} \\
& =\lambda_{\max } \\
& {\left[\begin{array}{l}
0.7668572 \\
2.7482815 \\
0.8884675 \\
0.3457014 \\
0.3086389
\end{array}\right]=\lambda_{\max }\left[\begin{array}{l}
0.1329523 \\
0.5292928 \\
0.152 / 221 \\
0.0591033 \\
0.0544946
\end{array}\right.}
\end{aligned}
$$

sehingga $\lambda_{\max }$ adalah :

$$
\begin{aligned}
& \lambda_{\max }\left(\frac{0.7668572}{0.1329523}\right)+\left(\frac{2.7482815}{0.5292928}\right)+\left(\frac{0.8884675}{0.1527221}\right)+\left(\frac{0.3457014}{0.0591033}\right)+\left(\frac{0.3086389}{0.0544996}\right) \\
& = \\
& =5.658013423 \\
& \text { iv. Consistency Ratio }(\mathrm{CR}) \\
& \quad \text { a) Consistency Index }(\mathrm{CI}) \\
& \qquad C 1=\frac{\lambda_{\max }-n}{n-1}=\frac{5.658013423-\mathrm{J}}{5-1}=0.16450336
\end{aligned}
$$


b) Consistensy Ratio (CR)

Untuk $\mathrm{n}=5$, maka nilai Ratio Index (RI) adalah 1.11, sehingga diperoleh CR sebagai berikut:

$$
C K=\frac{C I}{R I}=\frac{0.16450336}{1.11}=0.148201221 \approx 0.15
$$

2. Level Sub Krieria

Analisis menggunakan metode AHP pada level Sub Kriteria menerapkan perhitungan seperti pada level Kriteria diatas. Hasil perhitungan disajikan secara ringkas sebagai berikut:

i. Kriteria Lokasi

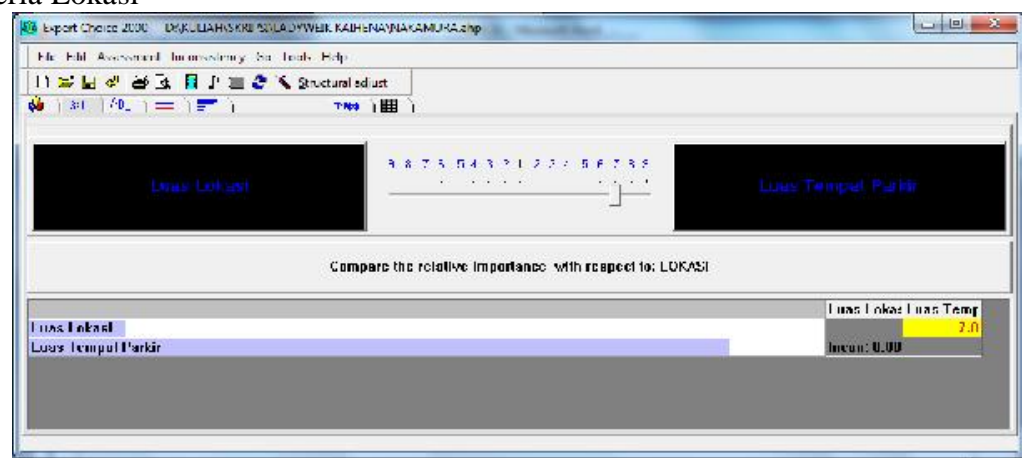

Pengolahan data kriteria lokasi dengan software expert choice

a) Matriks perbandingan berpasangan

$A=\left[\begin{array}{cc}1 & 1 / 7 \\ 1 & 1\end{array}\right]=\left[\begin{array}{cc}1 & 0.1428571 \\ 7 & 1\end{array}\right]$

b) Matriks perbandingan berpasangan yang dinormalisasi (kolom)

\section{$\left[\begin{array}{ll}0.125 & 0.125 \\ 0.875 & 0.875\end{array}\right]$ \\ $\left[\begin{array}{ll}0.875 & 0.875\end{array}\right]$}

c) Matriks bobot relatif yang dinormalisasikan

$W=\left[\begin{array}{l}0.125 \\ 0.875\end{array}\right]$

d) Eigen Value Terbesar $\left(\lambda_{\max }\right)$

e) Consistency Ratio (CR)

$$
\lambda_{\text {max }}=2
$$

$C I=\frac{\lambda_{\max }-n}{n-1}=\frac{2-2}{2-1}=0.00$

Untuk $\mathrm{n}=2$, nilai $\mathrm{RI}=0.00$, maka

ii. Kriteria Biaya Investasi

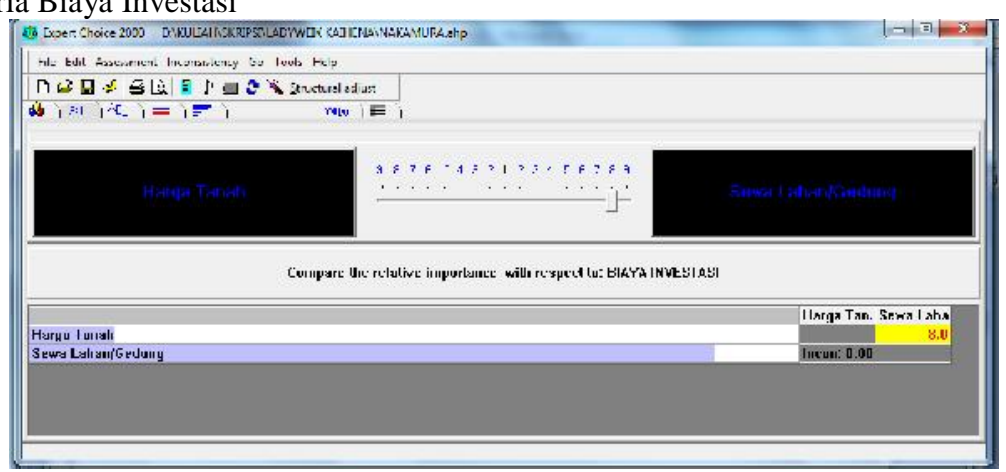

Pengolahan data kriteria biaya investasi dengan software expert choice

a) Matriks perbandingan berpasangan

$A=\left[\begin{array}{cc}1 & 1 / 8 \\ 8 & 1\end{array}\right]=\left[\begin{array}{cc}1 & 0.125 \\ 8 & 1\end{array}\right]$

b) Matriks perbandingan berpasangan yang dinormalisasi (kolom)

[0.1111111 0.1111111

0.8888889 U.৪৪४৪৪४у 
c) Matriks bobot relatif yang dinormalisasikan $W=\left[\begin{array}{l}0.1111111 \\ 0.8888889\end{array}\right]$

d) Eigen Value Terbesar $\left(\lambda_{\max }\right)$

e) Consistency Ratio (CR)

$$
\lambda_{\text {max }}=2
$$

$C I=\frac{\lambda_{\text {max }}-n}{n-1}=\frac{2-2}{2-1}=0.00$

Untuk $\mathrm{n}=2$, nilai $\mathrm{RI}=0.00$, maka

$$
\mathrm{CR}=\mathrm{CI} / \mathrm{RI}=0.00
$$

iii. Kriteria Pasar

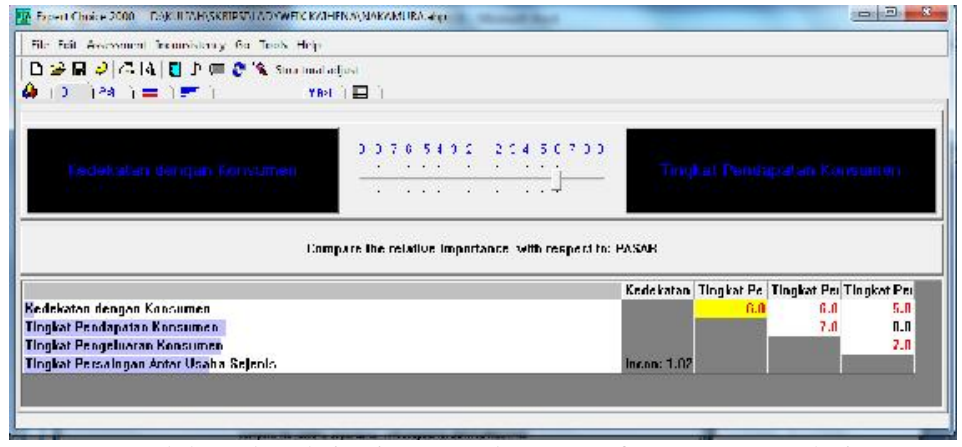

Pengolahan data kriteria pasar dengan software expert choice

a) Matriks perbandingan berpasangan

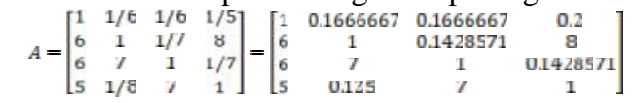

b) Matriks perbandingan berpasangan yang dinormalisasi (kolom)

$\begin{array}{llll}0.0555555 & 0.0201005 & 0.02005 / 5 & 0.0214067\end{array}$

$0.3333333 \quad 0.1206030 \quad 0.01 \% 19190.8562691$

$\begin{array}{llll}0.3333333 & 0.0442211 & 0.1203433 & 0.0152905\end{array}$

$\left[\begin{array}{llll}0.2777778 & 0.0150751 & 0.8121069 & 0.1070336\end{array}\right]$

c) Matriks bobot relatif yang dinormalisasikan

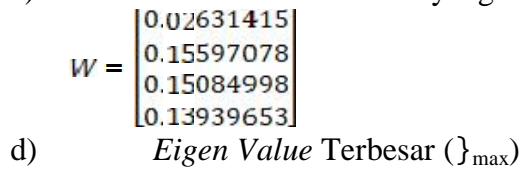

e)

$$
\begin{aligned}
& \text { Consistency Ratio (CR) } \\
& C^{\prime}=\frac{\lambda_{\max }-n}{n-1}=\frac{8.09456524-4}{4-1}=1.36485508 \\
& \text { Untuk } \mathrm{n}=4 \text {, nilai } \mathrm{RI}=0.90 \text {, maka } \\
& \mathrm{CR}=1.36485508 / 0.90=1.51650564 \approx 1.52
\end{aligned}
$$

iv. Kriteria Bahan Baku

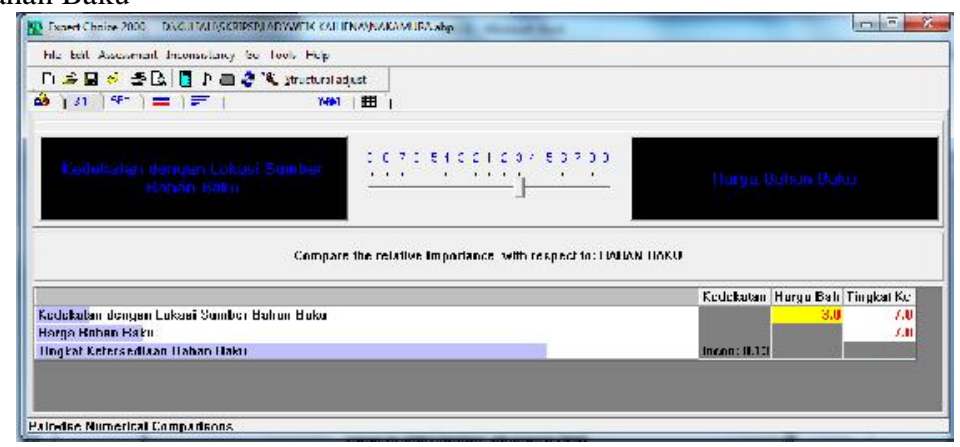

Pengolahan data kriteria bahan baku dengan software expert choice 
a) Matriks perbandingan berpasangan

$$
A=\left[\begin{array}{ccc}
1 & 1 / 3 & 1 / 7 \\
3 & 1 & 1 / 7 \\
7 & 7 & 1
\end{array}\right]=\left[\begin{array}{ccc}
1 & 0.3333333 & 0.1428571 \\
3 & 1 & 0.14285 / 1 \\
7 & \gamma & 1
\end{array}\right]
$$

b) Matriks perbandingan berpasangan yang dinormalisasi (kolom)

$\left|\begin{array}{lll}\text { 0.0909091 } & 0.04 & 0.1111111 \\ 0.2 / 2 / 2 / 2 & 0.12 & 0.1111111 \\ 0.6363636 & 0.84 & 0.7777778\end{array}\right|$

c) Matriks bobot relatif yang dinormalisasikan

$$
W=\left[\begin{array}{l}
0.07392 / 9 \\
0.1537762 \\
0.7463571
\end{array} \mid\right.
$$

d) Eigen Value Terbesar $\left(\lambda_{\max }\right)$

e) Consistency Ratio (CR)

$$
\lambda_{\max }=3.1356109
$$

$C l=\frac{\lambda_{\text {max }}-n}{n-1}=\frac{3.1356109-3}{3-1}=0.0678054$

Untuk $\mathrm{n}=3$, nilai $\overline{\mathrm{RI}}=0.84$, maka

$\mathrm{CR}=0.0678054 / 0.84=0.0807207 \approx 0.08$

v. Kriteria Infrastruktur Pendukung

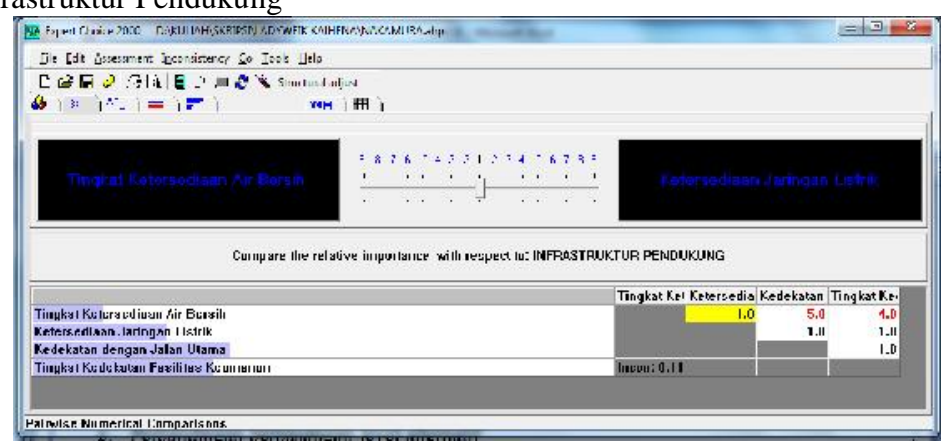

Pengolahan data kriteria infrastruktur pendukung dengan software expert choice

a) Matriks perbandingan berpasangan

$$
A=\left[\begin{array}{cccc}
1 & 1 & 1 / 5 & 1 / 4 \\
1 & 1 & 1 & 1 \\
5 & 1 & 1 & 1 \\
4 & 1 & 1 & 1
\end{array}\right]=\left[\begin{array}{cccc}
1 & 1 & 0.2 & 0.25 \\
1 & 1 & 1 & 1 \\
5 & 1 & 1 & 1 \\
4 & 1 & 1 & 1
\end{array}\right]
$$

b) Matriks perbandingan berpasangan yang dinormalisasi (kolom)

$\left[\begin{array}{llll}0.0909091 & 0.25 & 0.0625 & 0.0 / 69230 \\ 0.0909091 & 0.25 & 0.3125 & 0.30 / 6923 \\ 0.4545455 & 0.25 & 0.3125 & 0.30 / 6923 \\ 0.3636364 & 0.25 & 0.3125 & 0.30 / 6923\end{array}\right]$

c) Matriks bobot relatif yang dinormalisasikan

$$
W=\left[\begin{array}{l}
0.4364813 \\
0.9282828 \\
1.33 / 2430 \\
1.2350030
\end{array} \mid\right.
$$

d) Eigen Value Terbesar $\left(\lambda_{\max }\right)$

e) Consistency Ratio (CR)

$$
\lambda_{\max }=4.3035708
$$

$$
\begin{aligned}
C l= & \frac{\lambda_{\max }-n}{n-1}=\frac{4.3035 / 08-4}{4-1}=0.1011903 \\
& \text { Untuk } \mathrm{n}=4, \text { nilai RI }=0.90, \text { maka } \\
& \mathrm{CR}=0.1011903 / 0.90=0.1124336 \approx 0.11
\end{aligned}
$$

Perbandingan Karakteristik Sub Kriteria Menurut Alternatif Lokasi

Bandingkan setiap sub kriteria dan kriteria pada masing-masing lokasi dan jelaskan kenapa ada sub kriteria yang nilai rendah (penyebabnya dan dampak) dan yang nilai tinggi (penyebabnya dan manfaat/dampak positif) :

- $\quad$ Level Kriteria, menunjukkan inconsistency pada tingkat kepentingan relatif antar Sub Kriteria pada beberapa Kriteria. Kriteria Pasar, yakni saat Tingkat Pendapatan Konsumen < Tingkat Pengeluaran 
Konsumen dan Tingkat Pendapatan Konsumen > Tingkat Persaingan Antar Usaha Sejenis, Pemilik Nakamura menilai Tingkat Pengeluaran Konsumen < Tingkat persaingan antar usaha sejenis. Pada setiap lokasi terdapat luas tempat parkir, lokasi yang luas tempat parkirnya lebih besar dibandingkan dengan lokasi-lokasi yang lainnya adalah lokasi paso. Semua lokasi terpilih dan biaya investasi pada sub kriteria dan kriteria sangat konsisten. Sub kriteria yang nilainya sangat rendah Level Sub Kriteria, menunjukkan inconsistency pada perbandingan berpasangan dari alternatif Lokasi dari beberapa Sub Kriteria. Tingkat Ketersediaan Bahan Baku, yakni saat Passo > Tanah Tinggi, Passo < Urimesing, dan Urimesing > Batu Meja. Pemilik Nakamura menilai Tanah Tinggi dan Batu Meja memiliki nilai tingkat ketersediaan Bahan Baku lebih rendah daripada Paso dan Urimessing. Nilai Tingkat Ketersediaan Jaringan Listrik, yakni Passo > Tanah Tinggi, Passo < Batu Meja dan urimessing > batu meja, Pemilik Nakamura menilai Tanah Tinggi > Batu Meja. Nilai Tingkat Kedekatan Fasilitas Keamanan, paso > Tanah Tinggi dan urimessing > Batu meja. Pada sub kriteria ini ada kecenderungan ketidaksesuaian nilai kepentingan relatif antara Tanah Tinggi dan Batu Meja serta Passo dan Urimesing. Hal ini mempertimbangkan dari hasil penilian Tanah Tinggi lebih rendah daripada Batu Meja, dan selisih nilai kepentingan relatif antara Passo dan Urimessing adalah 1. Nilai terendah pada setiap pemilihan lokasi adalah : Tanah Tinggi dan Batu Meja, ini dilihat dari rendahnya infrastruktur pendukung dan ketersediaan tingkat keamanan, tetapi pada tingkat ketersediaan Bahan Baku Tanah Tinggi, Batu Meja dan Urimessing lebih unggul dibandingkan dengan Paso.

\section{Perbandingan Alternatif Lokasi}

- Bandingkan setiap lokasi berdasarkan sub kriteria dan kriterianya dan jelaskan kenapa ada lokasi yang nilai rendah (penyebabnya dan dampak) dan yang nilai tinggi (penyebabnya dan manfaat/dampak positif) : Dari hasil pengolahan data dengan Expert Choice menunjukkan lokasi Urimesing sebagai kandidat terkuat untuk pembangunan cabang tempat pijat Nakamura yang baru. Pilihan ini sesuai dengan kecenderungan prioritas pilihan pemilik tempat ini dalam memberikan nilai kepentingan relatif baik untuk membandingkan antar Kriteria, Sub Kriteria maupun alternative lokasi. Dalam hal ini terdapat pilihan pemilik Nakamura terhadap lokasi Urimesing memiliki kemungkinan untuk berubah apabila tingkat kepentingan relatif antar Kriteria mengalami perubahan. Dan dari analisis sensitivitas bertujuan memeriksa sejauhmana alternatif keputusan lokasi Urimesing dapat dipertahankan seiring perubahan tingkat kepentingan relatif antar Kriteria. Perubahan tingkat kepentingan relatif antar kriteria dilakukan secara berurutan menurut kriteria. Proses perubahan dilakukan dengan menaikkan dan menurunkan nilai bobot kriteria tertentu sampai terjadi perubahan alternatif keputusan lokasi. Lokasi yang nilainya rendah terdapat pada lokasi Batu Meja. Bila dibandingkan dengan lokasi Tanah Tinggi > dibandingkan dengan Batu Meja, ini membuktikan bahwa nilai terendah pada pemilihan lokasi baru cabang Nakamura yang dilakukan peninjauan ulang untuk lokasi terpilih tidak terlalu signifikan pada lokasi Batu Meja dan Tanah Tinggi. Sedangkan pada lokasi Paso dan Urimesing, pemilihan yang dilakukan oleh pemilik Nakamua lebih dominan ke lokasi Urimesing. Pada lokasi Paso memiliki keunggulan pada pemilihan lokasi dan tempat parkir yang lebih luas dibandingkan dengan lokasi yang lain. Dari beberapa lokasi terpilih untuk pembuatan cabang baru Nakamura Seitai adalah lokasi terpilih Urimesing.

\section{Karakteristik Keputusan Lokasi Berdasarkan Hasil Analisis Sensitivitas}

- Gunakan hasil perhitungan analisis sensitivitas untuk menjelaskan sampai sejauhmana keputusan lokasi yang direkomendasikan berdasarkan hasil analisis dengan metode AHP tetap konsisten dan kapan keputusan itu akan berubah :

- Hasil analisis sensivitas dengan pendekatan grafik memberikan batas nilai bobot perubahan alternatif keputusan lokasi Urimesing ke lokasi lain menurut Kriteria. Untuk beberapa Kriteria, batas nilai tersebut merupakan hasil interpolasi. Perubahan tingkat kepentingan relatif antar kriteria dilakukan secara berurutan menurut kriteria. Proses perubahan dilakukan dengan menaikkan dan menurunkan nilai bobot kriteria tertentu sampai terjadi perubahan alternatif keputusan lokasi. Keputusan ini dapat berubah apabila tingkat kepentingan relatif antar Kriteria mengalami perubahan. Analisis sensitivitas bertujuan memeriksa sejauhmana alternatif keputusan lokasi Urimesing dapat dipertahankan seiring perubahan tingkat kepentingan relatif antar Kriteria. Pada lokasi terpilih adalah lokasi Urimesing dan Paso, tetapi lokasi yang drkomendasikan lebih baik untuk semua lokasi terpilih adalah lokasi Urimesing. Keputusan dapat berubah jika kiteria Lokasi dan Biaya Investasi tidak konsisten. Jika dilihat dari prsentase maka lokasi Paso lebih unggul dalam pemilihan lokasi dan lain-lainnya, tetapi ada sedikit 
perbedaan yang terjadi pada ketersediaan Bahan Baku lebih unggul pada lokasi Urimessing, jadi dapat dilihat bahwa lokasi yang dapat dipilih untuk membuka cabang baru adalahPasso.Perubahan keputusan lokasi dari "Urimesing" menjadi "Passo" terjadi jika tingkat prioritas (bobot) kriteria meningkat menuju 100\% untuk kriteria Lokasi, Pasar dan Infrastruktur Pendukung, atau turun menuju 0\% untuk kriteria Biaya Investasi.

\section{KESIMPULAN}

Mengacu pada hasil penelitian dan pembahasan yang memperhatikan relevansinya dengan tujuan penelitian, maka dapat dibuat keputusan untuk lokasi pembangunan gedung cabang baru dari industri pijat "Nakamura Seitai" yang paling tepat adalah di "Urimesing". Untuk lokasi terpilih "Urimesing" dapat dilihat dari beberapa kriteria yaitu : kriteria lokasi dari hasil pengolahan data expert choice menunujukan lokasi urimesing merupakan kandidiat terkuat untuk pembangunan cabang tempat pijat Nakamura yang baru, biaya investasi untuk lokasi terpilih Urimesing lebih baik dan lebih relative bila dibandingkan dengan lokasi-lokasi yang lain, untuk tingkat ketersediaan bahan baku paso, tanah tinggi dan batu meja lebih rendah dibandingkan dengan Urimesing, dan infrastruktur pendukung dalam tingkat keamanan Urimesing lebih baik daripada lokasi yang lainnya sebagai penunjang untuk pembangunan lokasi tempat pijat cabang cabang Nakamura yang baru.

\section{DAFTAR PUSTAKA}

Byukyazici, M. and Sucu, M., (2003)., The Analytic Hierarchy and Analytic Network Processes, Journal of Mathematics and Statistics, Vol. 32, pp. 65-73.

Doumpos, M. and Zopounnidis, C., (2004)., Multicriteria Decision Aid Classification Methods, Kluwer Academic Publisher, New York.

Goodwin, P. and Wright, G., (2004)., Decision Analysis for Management Judgment, Third Edition, John Wiley \& Sons Ltd., England.

Triantaphyllou and Mann, (1995)., Using the Analytic Hierarchy Process for Decision Making in Engineering Applications : Some Challenges, Inter'l Journal of Industrial Engineering : Applications and Practice, Vol. 2, No. 1, pp. 35-44, 1995.

Saaty, T. L.,(2008)., Decision making with the analytic hierarchy process, Int. J. Services Sciences, Vol. 1, No. 1, pp 83-98.

Saaty, T. L., (1996)., Decision Making with dependence and Feedback: the Analitic Network Process, First Edition, RWS Publications, Pitsburgh.

Saaty, T. L., (1988)., The Analytic Hierarchy Process., New York: Pegamon Press. 